Journal of Development and Communication Studies, Vol. 8. No. 2, July -December, 2021 ISSN (Online \& Print): 2305-7432. http://www.devcomsjournalmw.org

\title{
Implications of the understanding of Entrepreneurship in Local Economic Development in Malawi
}

Charles Mwatsika, Management Studies Department, Faculty of Commerce, Malawi University of Business and Applied Sciences (MUBAS). Email: cmwatsika@mubas.ac.mw

\begin{abstract}
The study analyses knowledge about entrepreneurship which guides entrepreneurial behaviour in enterprises in Malawi in order to reflect on its implications in local economic development. Top-ofthe-mind definition which collects unaided responses from the top of respondents' mind was used. Definitions or explanations of entrepreneurship and entrepreneurial activities undertaken were recorded from 337 enterprises. Innovations carried out by the enterprises were measured in new products, new production methods, new markets and new enterprises together with the values realised. Content analyses, descriptive statistics and comparison of means were used to classify the definitions of entrepreneurship, entrepreneurial activities undertaken and compare values of innovations carried out. The study finds that entrepreneurship is predominantly defined as starting and managing one's own business, being self-employed and creating jobs in the economy. Petty income generating activities and subsistence oriented micro and small enterprises dominate. The prevailing understanding of entrepreneurship guides policy, education and training, SME finance, infrastructure development and support towards unproductive entrepreneurial activities which would not ignite economic development. Therefore, much as institutions are established to support SME sector growth and improve the environment for business, improving knowledge about productive entrepreneurship that guides SME policy, finance, entrepreneurship education and training is pertinent in Malawi.
\end{abstract}

Keywords: SME, entrepreneurial behaviour, entrepreneurship education, Malawi

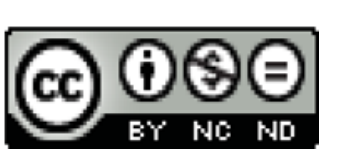

(C) 2021. The author. This work is licensed under the Creative Commons Attribution 4.0 International License (CC-By-NC-ND). Users may freely share and redistribute this work provided that the author and the Journal of Development and Communication Studies are fully acknowledged. Users may not tweak or remix and offer this work for sale. The full license may be accessed at https://creativecommons.org/licenses/by-nc-nd/4.0/

To cite this article: Mwatsika, C. (2021), Implications of the understanding of Entrepreneurship in Local Economic Development in Malawi, Journal of Development and Communication Studies, 8(2), 1-20. https://dx.doi.org/10.4314/jdcs.v8i2.1 


\section{Introduction}

Entrepreneurship has a long history of scholarly inquiry. Many scholars have explained the meaning of entrepreneurship (Gartner, 1988; Stevenson \& Jarillo, 1990; Mwatsika, Kambewa \& Chiwaula, 2018). The definitions of entrepreneurship are grounded in classical and neoclassical economic theories (Kirby, 2003). Cantillon (1755) is commonly cited as the originator of the term entrepreneurship (Kuratko \& Hodgetts, 2007). He presents entrepreneurship as an undertaking to buy raw materials at a certain price and resell at uncertain price for a profit. Say (1816) defines entrepreneurship as coordination of the factors of production to produce goods and services. Adam Smith (1723-1790) and David Ricardo (1772-1823) (Kirby, 2003) on the other hand, perceive entrepreneurship from the supply of capital. Knight (1921) perceives entrepreneurship as bearing uncertainty whereas Schumpeter (1934) presents entrepreneurship from the creative destruction perspective as carrying out innovations. Kirzner (1973) defines entrepreneurship as perception of opportunities to create new goods and services. Leibenstein (1968) discusses 'new' entrepreneurship in Schumpeter's (1934) sense and 'routine' entrepreneurship as superintendent of the production process thereby reflecting entrepreneurship as a management function as well.

As a result of these various perceptions, there is no commonly agreed definition of entrepreneurship. Hoselitz (1952) asserts that all aspects highlighted in the definitions of entrepreneurship such as perceiving opportunities, providing capital, coordinating factors of production, bearing uncertainty and undertaking innovations are key elements associated with entrepreneurship that it is impossible to just isolate one. Nonetheless, establishing a new organisation is a popular definition of entrepreneurship (Gartner, 1988; Dollinger, 2008; Scarborough, 2013). Scholars have moved away from further attempts to expound the meaning of entrepreneurship because chances are slim of reaching a consensus on the meaning of entrepreneurship (Cole, 1959).

Entrepreneurship became a very popular concept when Schumpeter (1934) linked it to economic development. Studies theoretically supported the link between entrepreneurship and economic development (Baumol, 1968; Leibenstein, 1968; Wennekers \& Thurik, 1999) and at the turn of the $21^{\text {st }}$ century more empirical analyses have supported the positive relationship between entrepreneurship and economic development (Chen, 2014; Hessels \& van Stel, 2011; Lee \& Xin, 2015; Stam \& van Stel, 2009; van Stel, Carree \& Thurik, 2005; Wong, Ho \& Autio, 2005). This has been possible with availability of data from projects, such as the Global Entrepreneurship Monitor (GEM), which measure entrepreneurship across a large number of countries.

Following theoretical and empirical studies that support existence of a positive relationship between entrepreneurship and economic development, entrepreneurship is highly promoted in developing countries as a strategy for achieving economic development (UNCTAD, 2015) against the background of high levels of poverty and unemployment. For instance, entrepreneurship is one of the strategies within Local Economic Development (LED) which was recommended for adoption in Southern Africa Development Community (SADC) (Wekwete, 2014). LED is the collective action of stakeholders (government, private 
sector organisations, public sector organisations and the local communities) in analysing, planning and implementing activities to initiate economic growth (Yatta, 2015). In Malawi, entrepreneurship and Small and Medium Enterprises (SME) sector growth is supported through various institutions which offer enterprise start-up support, education and training, facilitation of trade and access to markets, micro credit, establishment of rural growth centres and advocacy for legal and regulatory policy reforms (Masten \& Kandoole, 1997). It is therefore not surprising that GEM finds higher rates of Total early stage Entrepreneurial Activity (TEA) in developing countries than developed countries (GEM, 2018). Malawi had a TEA rate of 35.6 percent in 2012 against 12.8 percent for the United States of America (USA) (Dalious, Mandere, Jamali-Phiri \& Kaneka, 2012).

However, studies by van Stel et al. (2005), Stam and van Stel (2009) and Zaki and Rashid (2016) find that the relationship between entrepreneurship and economic development is positive for developed countries but negative for developing countries. Therefore, even if GEM finds higher entrepreneurial behaviour in developing countries and entrepreneurship is promoted as a strategy for economic development, it would not bring economic development in developing countries. The poor environments for business in developing countries (Legas, 2015; Olawale \& Garwe, 2010) are at first sight presumed the reason for poor performance of entrepreneurship.

The Doing Business report (World Bank Group, 2020) highlights poor environments for business in developing countries. The World Bank has therefore guided policy in some developing countries to improve in key thematic areas; starting a business, access to electricity, registering property, getting credit, protecting investors, tax administration, trading across borders, enforcing contracts and resolving insolvency. Many developing countries have implemented SME policies for decades to address the binding constraints in the environments for business. Malawi for instance, over time, has scored above 60 in the areas rated by Doing Business (World Bank Group, 2020) except for access to electricity, protecting investors, enforcing contracts and resolving insolvency. Efforts continue to be taken in developing countries to improve further the environment for business and to foster SME sector growth.

Nonetheless, the problem is that despite these efforts and promotion of the SME sector, Meressa (2020) and Cassim, Soni and Karodia (2014) observe that the expected results in economic development and creation of quality jobs are not achieved in Ethiopia and South Africa respectively. Their observations reflect the contexts of other developing countries such as Malawi (GOM, 2017) and thereby support the findings of Stam and van Stel (2009) and Zaki and Rashid (2016) that entrepreneurship does not bring about economic development in developing countries despite the higher entrepreneurial behaviour. The prevailing situation which Lafuente, Acs and Szerb (2018) call the Entrepreneurship Paradox is an area of study interest in developing countries and calls for investigation into other areas of possible cause. It was noted earlier that there are multiple perspectives of what entrepreneurship means from both the classical and neoclassical economic theorists; Cantillon (1755), Say (1816), Knight (1921), Schumpeter (1934) and Kirzner (1973). Perceiving entrepreneurship as coordinating factors of production, establishing a new 
organisation, perception and exploitation of opportunities, carrying out innovations or as management function has the potential to guide in undertaking contrasting activities as entrepreneurship with varying effects on the economy. Little is still known about the types and rates of entrepreneurship undertaken in developing countries and how it affects economic growth or not (Sheriff, Muffatto \& Cooper, 2016; Autio, 2008) because not many least developed and developing countries especially from Sub Saharan Africa are included in cross country entrepreneurship studies.

This study, therefore, isolates to investigate the understanding of entrepreneurship in Malawi, a least developed country in Southern Africa, assess what is undertaken as entrepreneurship and reflect on the potential implications in LED. Literature is reviewed on the prevailing understanding of entrepreneurship in developed countries and the focus of policy in order to contrast with the contexts of developing countries. The rest of the paper is presented as follows: first, a highlight of the evolution of the meaning of entrepreneurship and its various perceptions is presented. Thereafter, the prevailing understanding of entrepreneurship and policy focus between developed and developing countries is contrasted. The methodology used to conduct the study is presented followed by the results and their discussion. The discussion of the results focuses on the implications on policy and LED. The conclusion is drawn with recommendations and a highlight of areas for further study.

\section{Meanings of Entrepreneurship}

The definitions of entrepreneurship are grounded in Cantillon (1755), Say (1816), Schumpeter (1934) and Kirzner (1973). Cantillon (1755) is cited as the originator of the term entrepreneurship (Kuratko \& Hodgetts, 2007). He presents entrepreneurship as the perception of market discrepancies, buying of raw materials at certain prices to rework them up and resell at uncertain prices for a profit. Say (1816) defines entrepreneurship as the coordination of factors of production (capital, land and labour) to produce goods and services. Schumpeter (1934) defines entrepreneurship as carrying out innovations which disrupt markets, create new disequilibrium and ignite economic development and Kirzner (1973) defines entrepreneurship as perception and exploitation of opportunities. Various meanings of entrepreneurship are generated from these definitions.

From Cantillon's (1755) conceptualisation, individuals who undertake the entrepreneurial function are essentially self-employed, face risks on future resell prices and live under income uncertainty. It is therefore common to have definitions of entrepreneurship which highlight risk taking as a key element of entrepreneurship (Dollinger, 2008; Hisrich, Peters \& Shepherd, 2009) and self-employment to be perceived synonymously with entrepreneurship (Evans \& Jovanovic, 1989). Cantillon's (1755) entrepreneurship is the activity which moves markets towards the state of equilibrium (Walras, 1954) and therefore it is an important activity in economic theory (Cornelius, Landstrom \& Persson, 2006).

In Say's (1816) definition, coordination of factors of production is interpreted in two separate ways. First, it implies bringing together factors of production (capital, land and 
labour) to create the new organisation which produces goods and services and second, it implies management of factors of production within the production process, which Leibenstein (1968) refers to as 'routine' entrepreneurship. As such, some scholars define entrepreneurship simply as creation of a new organisation (Gartner, 1988; Dollinger, 2008) or a new company (Howell, 1972) or a new business (Hornaday \& Bunker, 1970; Hull, Bosley \& Udell, 1980; Mescon \& Montanari, 1981). Referring entrepreneurship to superintendent of the production process equates entrepreneurship to a management function (Leibenstein, 1968). The challenge of defining entrepreneurship as creation of a new business (Hornaday \& Bunker, 1970; Hull et al., 1980; Mescon \& Montanari, 1981) lies is in the definition of a business. Brown and Clow (2007) define business as any commercial activity which seeks profit by providing goods or services to others in exchange for money. In most developed countries a new business refers to a formal employing firm whereas in developing countries a new business includes any petty income generating activity. That means undertaking to start a new business may mean contrasting establishments between developed and developing countries. Starting a new business is nonetheless the meaning of entrepreneurship used in GEM methodology (Bosma et al., 2012) and it shows higher levels of entrepreneurial behaviour in developing countries than developed countries (GEM, 2018).

A reflection on the relative importance of the factors of production in undertaking entrepreneurship has Adam Smith (1723-1790) and David Ricardo (1772-1823) (Kirby, 2003) view entrepreneurship from the perspective of supplying capital. That highlights supply of capital as one of the important aspects of entrepreneurship. Knight (1921) on the other hand, differentiates risk taking from uncertainty bearing and emphasises that entrepreneurship is all about the latter. Some definitions, therefore, refer entrepreneurship as involving both financial risk taking and bearing of uncertainty (Hisrich et al., 2009; Dollinger, 2008).

While carrying out innovations is the modern understanding of entrepreneurship (Henrekson \& Sanandaji, 2014) and central to economic development, Schumpeter (1934) particularly refers to radical (discontinuous) innovations even though he acknowledges that incremental improvements can bring economic development over time. Mwatsika et al. (2018) highlight the categories of innovations and guiding definitions for each. Kirzner (1973) enters the space created by Schumpeter's (1934) theory and describes entrepreneurship as the perception and exploitation of opportunities brought by the discontinuous innovations. The opportunities refer to chances for imitation or application of new knowledge which may result in the creation of further innovations. Innovations, therefore, become a key output of entrepreneurship and other scholars have been guided by both Schumpeter (1934) and Kirzner (1973) to define entrepreneurship with reference to identification and exploitation of opportunities and creation of innovations (Drucker, 1985; Stevenson \& Jarillo, 1990; Gries \& Naude, 2011; Berglund \& Holmgren, 2013). Timmons (1989) and Hisrich et al. (2009), in their definitions of entrepreneurship, refer to innovations as something new with value. Therefore, scholars' definitions of entrepreneurship align with both the classical and neoclassical economic theories and highlight perception of opportunity, financial risk taking, uncertainty bearing, management of factors of 
production, creation of innovations, and creation of new organisations as key elements of entrepreneurship. Creation of a new organisation or a new business remains a commonly used definition of entrepreneurship (Gartner, 1988; Dollinger, 2008; Hornaday \& Bunker, 1970; Hull et al., 1980; Mescon \& Montanari, 1981).

Entrepreneurial behaviour undertaken in an economy is therefore frequently perceived through the prevalence of new organisations or new businesses. Although new organisations can be classified based on type of ownership (sole proprietorship or Limited Liability Corporation), age (new, young or mature), motivation for establishment (necessity motivated or opportunity motivated), objectives (profit making or non-profit making) and growth orientation (subsistence or high growth), size (micro, small, medium or large) is the most prominent distinction for new organisations. New organisations are expected to start small and grow over time (Churchill \& Lewis, 1983). As such it becomes convenient to identify new organisations with the prevalence of Micro Small and Medium Enterprises (SMEs) in the economy even though some organisations remain small for their entire life span. Prevalence of SMEs is therefore commonly used as the indicator of entrepreneurship and SMEs are perceived synonymously with entrepreneurship (Henrekson \& Sanandaji, 2014; Acs \& Virgill, 2009). The perception of entrepreneurship through SMEs blind sides the modern view of the concept as creation of innovations as Shane (2009) observes that most SMEs do not undertake innovations.

\section{Entrepreneurship in Developed and Developing Countries}

Perception of entrepreneurship through the prevalence of SMEs is common in both developed and developing countries. SMEs are important for economic development. They create over 65 percent of employment and contribute 55 percent to Gross Domestic Product (GDP) in developed Organisation for Economic Cooperation and Development (OECD) countries (OECD, 2004) and 60-90 percent of employment and contribute 25-65 percent to GDP in developing countries in Sub Saharan Africa (Lafuente et al., 2018).

The first difference between developed and developing countries is in the cut off points to distinguish SMEs from large organisations. The largest number of developed countries defines SMEs with a cut off point of zero to 250 employees (Ayyagari, Beck \& Demirquc-Kunt, 2003) although some have higher cut off points. For instance, Canada and the USA have cut off points for SME category of 499 employees (Berisha \& Pula, 2015) while China has a cut off point of 999 employees (Lee \& Xin, 2015). On the other hand, most developing countries in Sub Saharan Africa have cut off points of 100 employees (Hidayet et al., 2010). Therefore there would be some differences in the influence of SMEs on productivity and growth between developed and developing countries especially from those that are in the SME category in developed countries but are considered large in developing countries.

The second difference is in the levels of entrepreneurship recorded between developed and developing countries. Using self-employment as a proxy measure of entrepreneurship, the International Labour Organisation (ILO, 2015) finds higher levels of entrepreneurship in developing countries than developed countries. GEM (2018), furthermore, shows higher rates of Total early stage Entrepreneurial Activity (TEA) in 
developing countries than developed countries. In contrast, developed countries have higher levels of entrepreneurship than developing countries when new firm start-ups are used to measure entrepreneurship (Munemo, 2012). This highlights the differences in the formality of businesses between developed and developing countries. There is a higher prevalence of the informal sector in developing countries than developed countries with implications on job creation and economic growth (Auriol, 2013).

The third difference is in the effect of entrepreneurship on economic development. van Stel et al. (2005) and Zaki and Rashid (2016) find that entrepreneurship has a positive relationship with economic growth in developed countries but a negative relationship in developing countries. Furthermore, Fritsch and Mueller (2004) and Acs and Mueller (2008) find that new firm start-ups which are more prevalent in developed countries (Munemo, 2012) account for a high share of employment growth. That means most of the enterprises created in developed countries would create more jobs than those created in developing countries. There are therefore growing acknowledgements through observations (Meressa, 2020; Cassim et al., 2014) and studies (Stam \& van Stel, 2009) that entrepreneurship does not bring economic development in developing countries but in developed countries.

Various reasons have been put forward for the occurrence of this phenomenon. Baumol (1990) discusses productive and unproductive entrepreneurship where the environment for business is perceived a key influence on productivity of entrepreneurship. It is therefore accepted that for economic development to take place certain institutions must be present to guide productive entrepreneurial behaviour. Doing Business report (World Bank Group, 2020) highlights deficiencies in the environments for business in developing countries especially in Sub Saharan Africa. Other studies (Legas, 2015; Olawale \& Garwe, 2010) highlight challenges affecting SME sector growth and entrepreneurship in Sub Saharan African countries. Lafuente et al. (2018) find that economic performance is not linked to high rate of entrepreneurial behaviour as recorded in most developing countries by GEM (2018) but to a healthy institutional setting, the entrepreneurial ecosystem. They further note that Sub Saharan African countries have the weakest entrepreneurial ecosystems which negatively affect entrepreneurship and SME sector growth. Therefore the fourth difference between developed and developing countries is in the environments for business. World Bank Group (2020) observes that despite improvements registered in developing countries, they still lag far behind developed countries in the state of environments for business.

The poor environments for business are thereby perceived the main reason for lack of SME sector growth and the negative relationship between entrepreneurship and economic development in developing countries (World Bank Group, 2020; Lafuente et al., 2018). As such, other scholars have advocated the importance of instituting an entrepreneurial ecosystem to support entrepreneurial behaviour and economic development in developing countries (Lafuente et al., 2018; Mwatsika, 2018; Stam \& Spigel, 2016).

Developing countries, therefore, focus much attention to improve the environments for business and it is noted that SME policies in both developed and developing countries 
focus on similar thematic areas for improvement. A quick look at SME policies for Ethiopia (2016), Malawi (2012), Namibia (2016), Rwanda (2010), Tanzania (2002), Uganda (2015) and Zambia (2008) shows that SMEs are considered important for economic development in these countries. The SME policies focus on improving institutional, legal and regulatory frameworks, access to finance, access to markets, access to infrastructure, education and training, product development and value addition, technology and research and development (R\&D) and access to business development and support services among other areas. Some SME policies are specifically guided by Doing Business of the World Bank Group. Similarly, OECD (2019) highlights SME policy trends in OECD countries which focus on improving institutional and regulatory frameworks (access to markets, smart regulation and digitalisation), scaling up SME capacity (SME technology uptake, innovation and up-skilling) and creating supportive environments for SMEs (scaling up networks, access to finance and better infrastructure). However, the difference in SME policy between developed countries and developing countries is that policy in developing countries targets SME sector growth in general whereas policy in developed countries focuses deliberately on High Growth SMEs (HGSMEs) (OECD, 2010).

OECD (2010) defines HGSMEs as organisations with 10 employees at the beginning of the observation period which achieve a minimum of 20 percent growth annually for three consecutive years. It is necessary to note that high growth is a phase in the life cycle of a business (Churchill \& Lewis, 1983) although only a small proportion of SMEs enter that phase (Anyadike-Danes et al., 2009). HGSMEs are nonetheless of interest because studies have found that they innovate, increase productivity and create more net jobs (OECD, 2010). Mamburu (2017) found that HGSMEs add around twice as much real value to output and are more profitable than other firms. Stam and van Stel (2009) found that high growth organisations contribute to the macroeconomic growth in developed countries. It is of further interest to note that HGSMEs can be found in all economic sectors even primary sectors which are predominant in developing countries (Mamburu, 2017). The realisation of the importance of HGSMEs in developed countries guides policy towards the creation of a business environment which encourages innovation and competitiveness and support high growth (OECD, 2019; 2010). This contrasts significantly with the focus of SME policy in most developing countries in Sub Saharan Africa.

The review shows some of the key differences between developed and developing countries in types as well as levels of entrepreneurial behaviour, effects of entrepreneurship on economic development and the state of environments for business. Although developing countries have improved the state of environments for business substantially, the expected results in economic development and new quality jobs are not achieved (Meressa, 2020; Cassim et al., 2014). The SME policies in developed and developing countries aim to improve in similar areas with the main difference in that policy in developed countries focuses on HGSMEs whereas policy in developing countries focuses on SME sector growth in general. The focus on innovation, competition and high growth in developed countries is guided by neoclassical economic theories. As developing countries continue to improve the environments for business and establish institutions to support entrepreneurship, the 
effect on economic development will depend on entrepreneurial activities undertaken. The Theory of Planned Behaviour (Ajzen, 1991) Figure, 1, provides attitude, subjective norms and perceived behavioural control as the key elements which influence intentions towards particular behaviour.

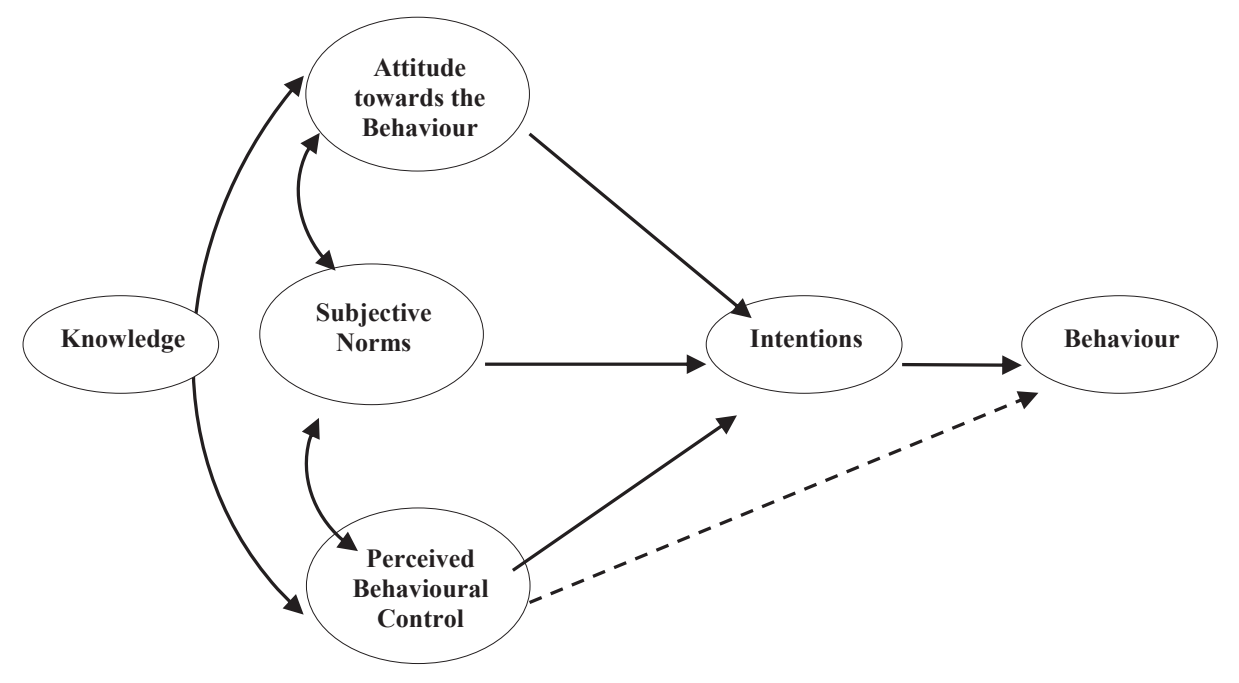

Figure 1: Theory of Planned Behaviour

Source: Ajzen (1991:182)

Within entrepreneurship, knowledge about the concept informs attitudes, subjective norms and perceived behavioural control. Attitude refers to the mental and neural state exerting readiness and influence upon the individual's objectives (Allport, 1935) and subjective norms are the individual's standard custom or beliefs which guide personal perceptions towards behaviour (Ajzen, 1991). Perceived behavioural control refers to self-efficacy which Bandura (1987) defines as an individual's self confidence in a given domain based on selfperceptions on skills and abilities. Entrepreneurial intention, which Thomson (2009) defines as self-acknowledged opinion to set up a new business, is positively influenced by these factors and scholars (Douglas \& Shepherd, 2002) found a strong link between intentions and actual entrepreneurial behaviour. Therefore within this framework, even though entrepreneurial behaviour is influenced by the context of institutions (Lafuente et al., 2018), knowledge about entrepreneurship informs the entrepreneurial behaviour undertaken. It is thereby necessary to investigate knowledge about entrepreneurship which guides what is undertaken in developing countries in order to reflect on its implications on local economic development.

\section{Methodology}

The study applied Top-of-the-mind definition approach (Lee, 2011) to collect unaided responses on the meaning of entrepreneurship from 337 enterprises in three cities (Blantyre, 
Lilongwe and Mzuzu) and three rural growth centres (Jenda in Mzimba, Monkey Bay in Mangochi and Thekerani in Thyolo) in Malawi. Respondents were asked to define or explain how they understood the term entrepreneurship from the top of their minds and furthermore to explain or list the activities their enterprises had undertaken which were considered acts of entrepreneurship based on their understanding of the term. Details were also collected on innovations the enterprises carried out over the past one year which included new products and the exchange values realised, new methods of production and their investment values and new markets entered and exchange values realised. Furthermore, details were collected on age of the enterprises, types of ownership, registration, motivations for establishment, objectives of enterprises, current numbers of employees and numbers of employees a year earlier. These details were used to categorise enterprises as either new or old, sole proprietorship or Limited Liability Corporation, formal or informal, necessity motivated or opportunity motivated, profit making or nonprofit making, size of enterprise (micro, small, medium or large) and movement in the number of employees to denote growth or lack of it. A new enterprise was defined as the one with a payroll above zero in a given year and did not exist in the previous year (Godin, Clemens \& Veldhuis, 2008). An interviewee filled questionnaire was used to collect the responses in face to face interviews with owners or managers of enterprises studied.

\section{Limitation of study}

Malawi is one of the least developed countries in Sub Saharan Africa. Although countries in Sub Saharan Africa have similarities, their populations differ in human development, education and literacy levels among others. Therefore, the transfer of the understanding of entrepreneurship and its implications on local economic development to other developing countries must be considered.

\section{Results and Discussion}

Table 1 presents descriptive statistics of the enterprises studied. The higher prevalence of sole proprietorship, necessity motivated and self-employed, micro and small enterprises is outstanding. These are the enterprises scholars (Auriol, 2013; Shane, 2009) have referred to as unproductive for economic development. Although 53.7 percent were formal (registered) enterprises, the registration referred to the Business Names Registration. The majority of enterprises still operated in the informal sector as there were only 5.6 percent limited liability companies in the sample.

\section{Table 1: Descriptive Statistics of Enterprises studied $(n=337)$}

$\begin{array}{lllcc}\text { No. } & \text { Detail } & \text { Category } & \text { Frequency } & \text { Percent } \\ \text { 1. } & \text { Type of Ownership } & \text { Sole proprietorship } & 318 & 94.4 \\ & & \text { Limited Liability Compar } & 19 & 5.6 \\ \text { 2. } & \text { Age of Enterprise } & \text { Old (Above 1 year old) } & 307 & 91.1 \\ & & \text { New (Up to 1 year old) } & 30 & 8.9\end{array}$




$\begin{array}{llccc}\text { 3. Motivation for establishment } & \text { Necessity motivated } & 273 & 81 \\ & & \text { Opportunity motivated } & 64 & 19 \\ \text { 4. } \quad \text { Objective of Enterprise } & \text { Profit making } & 325 & 96.4 \\ & & \text { Non-profit making } & 12 & 3.6 \\ \text { 5. Size of Enterprise } & \text { Micro } & 157 & 46.6 \\ & & \text { Self employed } & 98 & 29.1 \\ & \text { Small } & 71 & 21.1 \\ & & \text { Medium } & 9 & 2.7 \\ & & \text { Large } & 2 & 0.6 \\ \text { 6. } & \text { Formality of Enterprise } & \text { Formal (Registered) } & 181 & 53.7 \\ & & \text { Informal (Unregistered) } & 156 & 46.3\end{array}$

Through Table 2, it is observed that very few enterprises undertook innovations and the mean values of innovations were very low. Creating new methods of production and creating new markets were the least undertaken entrepreneurial activities denoting lack of investment in new systems and processes and lack of efforts to seek and enter new markets.

\section{Table 2: Number of Enterprises who carried out Innovations and their Value}

\section{FREQUENCY AND MEAN VALUES MK'000*}

\begin{tabular}{|c|c|c|c|c|c|c|c|}
\hline \multicolumn{8}{|c|}{$\mathrm{n}=337(100 \%)$} \\
\hline \multicolumn{2}{|c|}{ New Enterprises } & \multicolumn{2}{|c|}{ New Products } & \multicolumn{2}{|c|}{$\begin{array}{l}\text { New Production } \\
\text { Methods }\end{array}$} & \multicolumn{2}{|c|}{ New Markets } \\
\hline $\begin{array}{r}\text { Frequency } \\
\text { (Percent) }\end{array}$ & $\begin{array}{l}\text { Mean } \\
\text { Value }\end{array}$ & $\begin{array}{l}\text { Frequency } \\
\text { (Percent) }\end{array}$ & $\begin{array}{l}\text { Mean } \\
\text { Value }\end{array}$ & $\begin{array}{r}\text { Frequency } \\
\text { (Percent) }\end{array}$ & $\begin{array}{l}\text { Mean } \\
\text { Value }\end{array}$ & $\begin{array}{r}\text { Frequency } \\
\text { (Percent) }\end{array}$ & $\begin{array}{l}\text { Mean } \\
\text { Value }\end{array}$ \\
\hline $30(8.9 \%)$ & 1,981 & $84(25 \%)$ & 8,942 & $7(2 \%)$ & 1,281 & $4(1.2 \%)$ & 1,058 \\
\hline
\end{tabular}

${ }^{*}$ Exchange rate: Malawian Kwacha (MK) 745 = USD\$1

The results also showed that of the 30 new enterprises in the sample, none were limited liability companies. They were all sole proprietorship enterprises with a low average present worth of USD $\$ 2,659$ denoting low capitalisation of start-ups. At least 25 percent of enterprises created new products. However, most of the new products were new at organisation level and few at country level. Most new products were imitations from the internet which was cited as one of the sources of new product ideas by most enterprises that created new products. None of the enterprises studied had an R\&D programme for new products development.

Results on the understanding of entrepreneurship are presented in Table 3. It is interesting to note that creating jobs was perceived as the meaning of entrepreneurship by 
some respondents. In Malawi unemployment rate is 20.4 percent (GOM, 2017). As such entrepreneurship and small business enterprises are widely promoted, among the youths and marginalised groups, in order to create jobs but what entrepreneurship means is not explained through most communication. It is however not correct to perceive entrepreneurship as creating jobs because jobs can also be created by factors other than entrepreneurship. To other respondents, entrepreneurship meant a business or an SME thereby agreeing with Acs and Virgill (2009) that SMEs are commonly perceived synonymously with entrepreneurship.

\section{Table 3: Meanings of Entrepreneurship from Respondents}

\begin{tabular}{llcc} 
No. & \multicolumn{1}{c}{ Meaning of Entrepreneurship } & Frequency & Percent \\
1 & Creating Jobs & 55 & 16.3 \\
2 & Managing own business & 52 & 15.4 \\
3 & Starting a new business & 37 & 11.0 \\
4 & Entrepreneurship means a Business & 28 & 8.3 \\
5 & Being in Self-employment & 19 & 5.6 \\
6 & Small and medium enterprises & 10 & 3.0 \\
7 & Creating innovations in businesses & 3 & 0.9 \\
8 & Other & 11 & 3.3 \\
9 & I Don't Know & 122 & 36.2 \\
& Total & 337 & $\mathbf{1 0 0 . 0}$
\end{tabular}

Starting a new business, managing one's own business and being self employed are perceptions grounded in classical economic theories (Cantillon, 1755; Say, 1816) which were stated by 32 percent of respondents as the meaning of entrepreneurship. When that is compared to 0.9 percent of respondents who perceived entrepreneurship as creating innovations, it indicates that in Malawi, entrepreneurship is largely perceived through the classical economic theories and not the neoclassical economic theories (Schumpeter, 1934; Kirzner, 1973) which put entrepreneurship at the centre of economic development theory.

It is also striking that 36.2 percent of respondents did not know the meaning of entrepreneurship. Although most of these respondents were those with primary and secondary school education where entrepreneurship is not covered by curricula, they were the majority who operate self-employed, micro and small enterprises and represent a typical business owner/manager in Malawi. They are the people expected to be at the centre of local economic development especially in rural growth centres where entrepreneurship is one of the strategies for achieving economic growth and yet they lack knowledge about what entrepreneurship means.

The results on what the respondents considered entrepreneurial activities undertaken by their enterprises reflect the meanings of entrepreneurship held. Owning an enterprise (19.6\%), creating jobs (15.7\%) and the various day to day management activities $(11.9 \%)$ were considered entrepreneurial activities thereby supporting the respondents 
understanding of entrepreneurship as creating jobs, owning and managing a business. However, some respondents $(43.3 \%)$ did not know the activities undertaken which could be considered entrepreneurial whereas 9.5 percent felt that their enterprises did not undertake any entrepreneurial activities. It can therefore be summarised from the findings that entrepreneurship is commonly understood as starting a new business, managing one's own business, being in self-employment and creating jobs in the economy. This reflects the policy position in Malawi where start-ups and self-employment have been promoted and supported since the early 1980s (Masten \& Kandoole, 1997) and therefore entrepreneurship intuitively means starting and managing one's own business. This understanding of entrepreneurship is reflected upon its implications in local economic development.

The meanings of entrepreneurship found among enterprises in Malawi are grounded in classical economic theories (Cantillon, 1755; Say, 1816). Various institutions are established to support and grow the SME sector and to promote entrepreneurial behaviour (Masten \& Kandoole, 1997) whereas the SME Policy (GOM, 2012) focuses on improving the environment for business. But when classical and neoclassical economic theories of entrepreneurship are reflected upon, entrepreneurship grounded in classical economic theories such as undertaking self-employment, starting a new business or other petty income generating activities is found to be unproductive (Shane, 2009). It is neoclassical economic theories (Schumpeter, 1934; Kirzner, 1973) that place entrepreneurship at the centre of Economic Development Theory which guide towards productive entrepreneurship for economic development and thereby anchor the modern understanding of entrepreneurship (Henrekson \& Sanandaji, 2014). Entrepreneurship is perception of opportunities and undertaking innovations (Schumpeter, 1934; Kirzner, 1973). It is opportunity motivated and it is growth oriented new firms which are productive for economic development (Stam \& van Stel, 2009). Therefore the knowledge about entrepreneurship which guides institutions towards promotion and support of entrepreneurial behaviour is very important.

The understanding of entrepreneurship in Malawi is expected to influence policy on entrepreneurship promotion and support, entrepreneurship education and training, SME finance, infrastructure development and therefore overall effect on local economic development. Entrepreneurship is promoted among the youth and marginalised populations against the background of high levels of poverty and unemployment. Initiatives are undertaken to encourage many people to be self-employed, to start and run micro and small enterprises or any petty income generating activities thereby promoting entrepreneurship as starting and managing of one's own business and creating jobs in the economy.

Universities and Technical Colleges offer entrepreneurship education in their curricula. Studies link entrepreneurship education to entrepreneurial behaviour (Dickson, Solomon \& Weaver, 2008) but what is perceived as entrepreneurship guides curricula development and pedagogy. The main objective of entrepreneurship education in Malawi is to enable many graduates to start and run their own business since unemployment is high in the country. With the emphasise on self-employment and graduate start-ups, 
entrepreneurship education is guided by the understanding of entrepreneurship as starting and running one's own business and creating jobs in the economy as found in the study. Research and development for the creation of new knowledge and innovations is not emphasised upon in current university curricula.

Doing Business report (World Bank Group, 2020) highlights improvement in access to credit in Malawi. Nonetheless, this could largely refer to access to micro credit towards subsistence oriented and petty income generating activities undertaken by marginalised women groups. There are many Micro Finance Institutions (MFI) and Savings and Credit Co-operations (SACCO) which facilitate access to credit for women empowerment. Access to finance for enterprise start-up and growth is still a major challenge among SMEs in the country although the Government initiative, the National Economic Empowerment Fund (NEEF) aims to support the youths with access to capital. SME finance is generally guided by the understanding of entrepreneurship as self-employment, creating own businesses and creating jobs in the economy. Finance for R\&D and innovation is not available in Malawi.

On infrastructure development, the Ministry of Local Government and Rural Development through the Local Development Fund (LDF) is constructing rural growth centres in selected districts. The rural growth centres are expected to ignite sustained economic development and entrepreneurship is one of the key strategies for economic growth. However, among the key infrastructure being constructed are markets for micro and small traders. There is higher prevalence of subsistence oriented micro and small enterprises in rural growth centres which reflect the perceptions of entrepreneurship in the country. Rural growth centres lack in productive entrepreneurship that would anchor economic revolution which they are expected to ignite. Overall, the SME policy in Malawi (GOM, 2012) aims to support SME sector growth but the focus is on subsistence oriented enterprises which are unproductive. As a result, industries are uncompetitive with low productivity and low export drive thereby Malawi ranks poorly on the Global Competitiveness Index (Schwab, 2019). Although efforts have been directed to improve the environment for business, initiatives are inadequate to improve the entrepreneurial activities undertaken and the country ranks poorly on the Global Entrepreneurship Index as well (Acs et al., 2018). Therefore the country experiences higher levels of unemployment, poverty and poor macroeconomic performance despite adoption of institutions to spur entrepreneurial behaviour, the efforts to improve the environment for business and the higher TEA rates.

The context of Malawi supports studies by Stam and van Stel (2009) that entrepreneurship does not bring about economic development in developing countries. However, one of the major challenges for Malawi could be that knowledge about entrepreneurship is predominantly grounded in classical economic theories (Cantillon, 1755; Say, 1816) and guide institutions to support self-employment, subsistence oriented business start-ups and other petty income generating activities. Entrepreneurship would influence economic development if it is grounded in neoclassical economic theories (Schumpeter, 1934; Kirzner, 1973) and institutions promote and support innovation, competitiveness and high growth. Policy, education and training, SME finance and 
infrastructure development needed to focus on supporting opportunity motivated and growth oriented firms which can enhance industry productivity and create quality jobs. There is therefore the need for key stakeholders to weigh up poverty alleviation initiatives through petty income generation activities against economic growth programmes through entrepreneurship.

\section{Conclusion}

The study found that knowledge about entrepreneurship in enterprises in Malawi is grounded in classical economic theories. Entrepreneurship is predominantly defined as starting and managing one's own business, being self-employed and creating jobs in the economy. This reflects the policy position where entrepreneurship is promoted as starting a business and it is encouraged in order to create jobs. This is the understanding of entrepreneurship which guides institutions; education and training, SME finance, infrastructure development and other entrepreneurship development initiatives. However, entrepreneurship guided by the knowledge found in the study is unproductive. Economic development arises from perceiving opportunities and carrying out innovations which disrupt markets, ignite competition, enhance productivity and create more quality jobs. This is knowledge about entrepreneurship guided by neoclassical economic theories. Therefore much as initiatives are undertaken to improve the environment for business, to correct the binding constraints which affect SME sector growth, improving the knowledge about productive entrepreneurship and what is undertaken, is pertinent for economic development in Malawi.

It is recommended that SME policy and institutions which support SME sector growth and promote entrepreneurial behaviour be guided by appropriate knowledge about productive entrepreneurship. Education and training, SME finance and infrastructure development need to be grounded in modern understanding of entrepreneurship as perception of opportunities and carrying out innovations that bring change and ignite economic development. That means entrepreneurship development programmes should focus on establishing opportunity motivated and growth oriented firms rather than the subsistence oriented micro and small enterprises and other petty income generating activities. As such there is need for key stakeholders of local economic development to contrast poverty alleviation initiatives through petty income generating activities from entrepreneurship programmes for initiating economic growth.

If the context of Malawi reflects other developing countries in Sub Saharan Africa in terms of the understanding of entrepreneurship and the higher prevalence of unproductive entrepreneurial activities, then it would explain the reasons entrepreneurship does not bring expected economic development in developing countries. And thereby contribute to knowledge that despite establishing institutions and trying to create the entrepreneurial ecosystem as advocated by scholars, the knowledge about productive entrepreneurship which guides initiatives undertaken is equally important.

Studies are still required in Sub Saharan Africa to understand the prevailing knowledge about entrepreneurship which guides institutions that support entrepreneurial 
behaviour and SME sector growth. Further studies are required to inform on entrepreneurial activities undertaken in developing countries, innovations carried out at organisation, country or global level and the values of such innovations in order to determine the level of productivity of entrepreneurship. That would inform policy the areas for improvement to enhance effectiveness of entrepreneurship in local economic development in developing countries.

\section{References}

Acs, Z., \& Mueller, P. (2008). Employment effects of Business Dynamics: Mice, Gazelles and Elephants. Small Business Economics, 30(1), 85-100.

Acs, Z. J., Szerb, L., Lafuente, E., \& Lloyd, A. (2018). The global entrepreneurship index 2018. The Global Entrepreneurship and Development Institute, Washington D.C. USA.

Acs, Z., \& Virgill, N. (2009). Entrepreneurship in developing countries. Jena Economic Research Papers, No. 2009, 023, Friedrich Schiller University, Jena and Max Planck Institute of Economics. Jena.

Ajzen, I. (1991). Theory of planned behaviour. Organizational Behaviour and Human Decision Processes, 50, 179-211.

Allport, G.W. (1935). Attitudes. In C.M. Murchison (Ed.), Handbook of Social Psychology. Winchester, MA: Clark University Press.

Anyadike-Danes, M., Bonner, K., Hart, M., \& Mason, C. (2009). Measuring Business Growth in High Growth Firms and their contribution to employment in the UK, NESTA.

Auriol, E. (2013). Barriers to formal entrepreneurship in developing countries. Contribution for the Enterprise Sector: Providing employment and sharing risk, Chapter, World Bank.

Autio, E. (2008). High and low aspiration entrepreneurship and economic growth in low income economies. Paper presented at the UN-WIDER Workshop on Entrepreneurship in Economic Development, Helsinki, Finland, 21-23 August.

Ayyagari, M., Beck, T., \& Demirquc-Kunt, A. (2003). Small and medium enterprises across the globe: A new database. Working Paper 3127, World Bank.

Bandura, A. (1987). Self-Efficacy: The Exercise of Control. New York: W. H. Freeman and Company.

Baumol, W. J. (1990). Entrepreneurship, productive, unproductive and destructive. Journal of Political Economy, 98(5), 893-921.

Baumol, W. J. (1968). Entrepreneurship in Economic Theory. American Economic Review, 58(2), 64-71.

Berglund, K., \& Holmgren, C. (2013). Entrepreneurship education in policy and practice. International Journal of Entrepreneurial Venturing, 5 (1), 9-27.

Berisha, G., \& Pula, J. S. (2015). Defining small and medium enterprises: A critical review. Academic Journal of Business Administration, Law and Social Sciences, 1(1), 17-28.

Bosma, N., Coduras, A., Litovsky, Y., \& Seaman, J. (2012). GEM Manual: A report on the design, data and quality control of the Global Entrepreneurship Monitor. GEM Consortium. 
Brown, B.J., \& Clow, J.E. (2007). Glencoe Introduction to Business, Glencoe/McGraw-Hill, New York.

Cantillon, R. (1755). Essay on the Nature of Trade in General. London: Henry Higgs (edition and translation 1959).

Cassim, S., Soni, P., \& Karodia, A. (2014). Entrepreneurship policy in South Africa. Arabian Journal of Business and Management Review, 3(9), 29-43.

Chen, C. C. (2014). Entrepreneurship, economic growth and employment: A case study of Taiwan. Hitotsubashi Journal of Economics, 55, 71-88.

Churchill, N. C., \& Lewis, V. L. (1983). The five stages of Small Business Growth. Harvard Business Review.

Cole, A. H. (1959). Business enterprise in its social setting. Cambridge: Harvard University Press.

Cornelius, B., Landstrom, H., \& Persson, O. (2006). Entrepreneurial studies: The dynamic research front of developing social science. Entrepreneurship Theory and Practice, 30(3), 375-398.

Dalious, M, Mandere, G., Jamali-Phiri, M., \& Kaneka, B. (2012). Global entrepreneurship monitor Malawi report 2012. Global Entrepreneurship Research Association, UK.

Dickson, P., Solomon, G., \& Weaver, K. (2008). Entrepreneurial section and success: Does education matter? Journal of Small Business and Enterprise Development, 15(2), 239-258.

Dollinger, M. J. (2008). Entrepreneurship strategies and resources (4th edition). Marsh Publications, Lombard, Illinois, USA.

Douglas, E.J., \& Shepherd, D. A. (2002). Self employment as a career choice: Attitudes, entrepreneurial intentions and utility maximization. Entrepreneurship Theory and Practice, 26(3), 81-90.

Drucker, P. F. (1985). Innovation and entrepreneurship: Practice and Principles. New York: Harper Business.

Evans, D. S., \& Jovanovic, B. (1989). An estimated model of entrepreneurial choice under liquidity constraints. The Journal of Political Economy, 97, 808-827.

Fritsch, M., \& Mueller, P. (2004). The effects of new Business Formation on Regional Development over time. Regional Studies, 38(8), 961-975.

Gartner, W. B. (1988). 'Who is an entrepreneur?' is the wrong question. American Journal of Small Business, 12(4)11-32.

Global Entrepreneurship Monitor (2018). Global Entrepreneurship Monitor Report 2017-2018, Wellesley, MA, Babson College.

Godin, K., Clemens, J., \& Veldhuis, N. (2008). Measuring entrepreneurship - conceptual frameworks and empirical indicators. Studies in Entrepreneurship and Markets, Fraser Institute, Vancouver, British Columbia, Canada.

Government of the Federal Democratic Republic of Ethiopia (2016). Micro and Small Enterprise Development Policy and Strategy. Ministry of Urban Development and Housing.

Government of Malawi (2017b). Economic development document for Malawi. Ministry of Finance Economic Planning and Development, Lilongwe, Malawi. 
Government of Malawi (2012). Micro, Small and Medium Enterprises Policy Strategy for the Republic of Malawi: Enabling Enterprise Growth in Malawi (2012-2017). Ministry of Trade and Industry, Malawi.

Gries, T., \& Naude, W. A. (2011). Entrepreneurship and human development: A capability approach. Journal of Public Economics, 3(1), 216-224.

Henrekson, M. \& Sanandaji, T. (2014). Small business activity does not measure entrepreneurship. National Academy of Sciences, 111(5), 1760-1765.

Hessels, J., \& van Stel, A. (2011). Entrepreneurship, export orientation and economic growth. Small Business Economics, 37: 255-268.

Hidayet, K., Canan, S., Onur, S., \& Hakam, M. (2010). The importance of SMEs in developing economies. $2^{\text {nd }}$ International Symposium on Sustainable Development, June, 8-9, Sarajevo.

Hisrich, R., Peters, M., \& Shepherd, D. (2009). Entrepreneurship. McGraw-Hill.

Hornaday, J., \& Bunker, C. (1970). The nature of the entrepreneur. Personnel Psychology, 23, 47-54.

Hoselitz, B. F. (1952). Entrepreneurship and Economic Growth. American Journal of Economics and Sociology, 12(1), 97-110.

Howell, R. P. (1972). Comparative profiles: Entrepreneurs versus the hired executive: San Francisco peninsula semiconductor industry. In A. C Cooper \& J. L. Kornives (Eds.) Technical entrepreneurship: A symposium. Milwaukee: Centre for Venture Management, 47-62.

Hull, D. L., Bosley, J. J., \& Udell, G. G. (1980). Reviewing the heffalump: Identifying potential entrepreneurs by personality characteristics. Journal of Small Business Management, 18, 11-18.

International Labour Organisation (2015). Small and medium-sized enterprises and decent and productive employment creation. International Labour Conference, 104 $4^{\text {th }}$ Session, International Labour Office, Geneva.

Kirby, D. (2003). Entrepreneurship. McGraw-Hill.

Kirzner, I. (1973). Competition and Entrepreneurship, Chicago: University Press, Chicago.

Knight, F. H. (1921). Risk, uncertainty and profit. Houghton Mifflin, Boston.

Kuratko, D. F., \& Hodgetts, R. M. (2007). Entrepreneurship: Theory, process and practice, (7th Edition), Thomson South-Western.

Lafuente, E., Acs, Z., \& Szerb, L. (2018). The entrepreneurship paradox: More entrepreneurs are not always good for the economy- The role of the entrepreneurial ecosystem on economic performance in Africa. SSRN Working Paper Series.

Lee, C. J. (2011). Understanding bank service quality in customers' terms: an exploratory analysis of top-of-mind definition. International Journal of Business and Social Sciences, 2(21).

Lee, K., \& Xin, S. (2015). Firm size and economic growth in China. Journal of International and Area Studies, 22(1), 93-112.

Legas, H. (2015). Challenges to entrepreneurial success in Sub Saharan Africa: A comparative perspective. European Journal of Business and Management, 7(11), 23-35. 
Leibenstein, H. (1968). Entrepreneurship and development. American Economic Review, $58(2)$.

Mamburu, M. (2017). Defining high-growth firms in South Africa. WIDER Working Paper 2017/107, UNU-WIDER.

Masten, J., \& Kandoole, B. (1997). The capacity of small and medium enterprises support in Malawi to support small business expansion. Lilongwe, Malawi: Malawi Institute of Management.

Meressa, H. A. (2020). Growth of micro and small scale enterprises and its driving factors: Empirical evidence from entrepreneurs in emerging region of Ethiopia. Journal of Innovation and Entrepreneurship, 9(11), 1-22.

Mescon, T., \& Montanari, J. (1981). The personalities of independent and franchise entrepreneurs: An empirical analysis of concepts. Journal of Enterprise Management, 3(2), 149-159.

Munemo, J. (2012). Entrepreneurship in developing countries: Is Africa different? Journal of Developmental Entrepreneurship, 17(1), 1-12.

Mwatsika, C. (2018). The ecosystem perspective of entrepreneurship in local economic development. Journal of Economics and Sustainable Development, 9(12), 94-114.

Mwatsika, C., Kambewa, P., \& Chiwaula, L. (2018). Untangling the concept of entrepreneurship towards a common perspective. African Journal of Business Management, 12(14), 451-470.

Olawale, F., \& Garwe, D. (2010). Obstacles to the growth of new SMEs in South Africa: A principal component analysis approach. African Journal of Business Management, 4(5), 729-738.

Organisation for Economic Cooperation and Development (2019). OECD SME and Entrepreneurship Outlook: Policy Highlights. OECD.

Organisation for Economic Cooperation and Development (2010). High growth enterprises: What governments can do to make a difference, OECD studies on SMEs and entrepreneurship. Organisation for Economic Cooperation and Development, Paris.

Organisation for Economic Cooperation and Development (2004). Promoting Entrepreneurship and innovative SMEs in a Global economy: Towards a more responsible and inclusive globalization, $2^{\text {nd }}$ OECD Conference of Ministers responsible for SMEs, Istanbul, Turkey, OECD.

Republic of Namibia (2016). National Policy on Micro, Small and Medium Enterprises in Namibia, 2016-2021. Ministry of Industrialization, Trade and SME Development, Namibia.

Republic of Rwanda (2010). Small and Medium Enterprises Development Policy. Ministry of Trade and Industry, Rwanda.

Republic of Uganda (2015). Uganda Micro, Small and Medium Enterprises Policy: Sustainable MSMEs for wealth creation and socio-economic transformation. Ministry of Trade, Industry and Cooperatives, Uganda.

Republic of Zambia (2008). The Micro, Small and Medium Enterprise Development Policy. Ministry of Commerce, Trade and Industry, Zambia. 
Say, J. A. (1816). A Treatise on Political Economy. London: Sherwood, Neeley and Jones.

Scarborough, N. (2013). Essentials of entrepreneurship and small business management, Sixth Edn. Pearson.

Schumpeter, J. A. (1934). The theory of economic development. Cambridge, MA: Harvard Economic Studies.

Schwab, K. (2019). The global competitiveness report. World Economic Forum, Geneva.

Shane, S. (2009). Why encouraging more people to become entrepreneurs is bad public policy. Small Business Economics, 33(2): 141-149.

Sheriff, M., Muffatto, M., \& Cooper, S. (2016). Measuring entrepreneurship environments in Africa: challenges in using international reports. International Journal of Entrepreneurship and Innovation Management, 20 (1/2), 20-44.

Stam, E., \& Spigel, B. (2016). Entrepreneurial Ecosystem. Utrecht School of Economics, Discussion Paper Series 16-13.

Stam, E., \& van Stel, A. (2009). Types of entrepreneurship and economic growth. Research paper 2009/47, UNU Wider, Helsinki.

Stevenson, H. H., \& Jarillo, J. C. (1990). A paradigm of entrepreneurship: Entrepreneurial management. Strategic Management Journal, 11, 17-27.

Thomson, E. R. (2009). Individual entrepreneurial intent: Construct clarification and development of an internationally reliable metric. Entrepreneurship Theory and Practice, 33(3), 669-694.

Timmons, J. (1989). The Entrepreneurial Mind. Boston: Brick House.

United Nations Conference on Trade and Development (2015). Promoting entrepreneurship for development. Geneva.

United Republic of Tanzania (2002). Small and Medium Enterprise Development Policy. Ministry of Industry and Trade, Tanzania.

van Stel, A., Carree, M., \& Thurik, R. (2005). The effect of entrepreneurial activity on national economic growth. Small Business Economics, 24(3), 311-321.

Walras, L. (1954). Elements of pure economics or the theory of social wealth. London: George Allen and Urwin.

Wekwete, K. (2014). Local government and local economic development in Southern Africa. Commonwealth Local Government Forum.

Wennekers, S., \& Thurik, R. (1999). Linking Entrepreneurship to Economic Growth. Small Business Economics, 13, 27-55.

Wong, B., Ho, Y., \& Autio, E. (2005). Entrepreneurship, innovation and economic growth: Evidence from GEM Data. Small Business Economics, 24(3), 335 - 350.

World Bank Group (2020). Doing business 2020: Comparing business regulation in 190 economies. Washington, DC: World Bank Group.

Yatta, F. (2015). Local economic development in Africa: Implementation, constraints and prospects, Platforma, CLGF.

Zaki, I. M. \& Rashid, N. H. (2016). Entrepreneurship impact on economic growth in emerging countries. The Business and Management Review, 7(2), 31-39. 